\title{
Effect of Spacing and Intercropping on the Growth of Jatropha curcas and Availability of Light under Agroforestry System in Tamil Nadu, India
}

\author{
V. Subbulakshmi ${ }^{*}$, K. Srinivasan ${ }^{2}$, M.P. Divya ${ }^{2}$ and S. Mani ${ }^{2}$ \\ ${ }^{1}$ ICAR-Central Arid Zone Research Institute, Regional Research Station, \\ Bikaner, Rajasthan, India \\ ${ }^{2}$ Tamil Nadu Agricultural University, Coimbatore, Tamil Nadu, India \\ *Corresponding author
}

\begin{tabular}{|c|c|}
\hline & A B S T R A C T \\
\hline & \multirow{6}{*}{$\begin{array}{l}\text { An agroforestry experiment was conducted with three and a half year old Jatropha curcas } \\
\text { plantation at Mettupalayam, Tamil Nadu to find out the optimum spacing of } J \text {. curcas for } \\
\text { intercropping. The growth characteristics of Jatropha curcas were significantly influenced } \\
\text { by different spacings of } J \text {. curcas and intercrops. } J \text {. curcas recorded highest plant height } \\
(310 \mathrm{~cm}) \text {, number of branches }(14.66) \text { and crown diameter }(342.8 \mathrm{~cm}) \text { at wider spacing of } \\
4 \mathrm{~m} \times 3 \mathrm{~m} \text {. Different intercrops also significantly influenced the growth characters of } \\
J . \text { curcas. } J \text {. curcas at } 4 \mathrm{~m} \times 3 \mathrm{~m} \text { spacing with cowpea recorded the highest plant height } \\
(332 \mathrm{~cm}) \text { and crown diameter }(268 \mathrm{~cm}) \text {. The number of branches of } J \text {. curcas was also } \\
\text { found to be highest at } 4 \mathrm{~m} \times 3 \mathrm{~m} \text { spacing with cowpea }(15.7) \text {. There was a significant } \\
\text { difference in availability of light under different spacings of } J \text {. curcas. Maximum light was } \\
\text { intercepted at wider spacing of } J . \text { curcas }(4 \mathrm{~m} \times 3 \mathrm{~m}) \text {, which was } 732 \times 100 \text { Lux in the } \\
\text { morning and } 883 \times 100 \text { Lux in the afternoon. The study concluded that planting of } J \text {. } \\
\text { curcas at } 4 \mathrm{~m} \times 3 \text { m spacing is beneficial for the growth and development of } J \text {. curcasas } \\
\text { well as intercrops and legume based intercrops help to increase the growth of } J \text {. curcas in } \\
\text { agroforestry system. }\end{array}$} \\
\hline & \\
\hline $\begin{array}{l}\text { Spacing, } \\
\text { Intercropping, } \\
\text { Jatropha curcas }\end{array}$ & \\
\hline Article Info & \\
\hline $\begin{array}{l}\text { Accepted: } \\
\text { 10 May } 2019 \\
\text { Available Online: } \\
\text { 10 June } 2019\end{array}$ & \\
\hline & \\
\hline
\end{tabular}

\section{Introduction}

In recent years, biofuels derived from plant species has been gaining interest due to their potential to improve the energy security. It helps to mitigate climate change by reducing GHG emissions. India started bio-diesel blending from 2015 and National Policy on Biofuels-2018 has the objective of reaching $20 \%$ ethanol-blending and 5\% biodieselblending by the year 2030 (MPNG, 2018). Among the many oil seed bearing plant species, which yield oil as a source of energy in the form of bio-diesel, Jatropha curcas L. has been identified as a suitable species due to its various favourable attributes like adaptability in a wide range of agro-climatic conditions, short gestation period, hardy nature, high oil recovery and quality of oil etc. J. curcas is a plant native to Latin America belongs to Euphorbiaceae family and can grow upto 3-4 m high on marginal soils. Seeds of $J$. curcas contain about 35 per cent of non-edible oil (Henning, 2003). It can be 
grown as agroforestry tree, planted on degraded lands, farm boundaries, both sides of railway track, road sides, and fallow lands.

To overcome the problem of food and environmental security the potential of agroforestry need to be fully exploited. Integration of tree species in agricultural production system impart stability besides risk reduction, since even if one component of the system fails, other species would give harvest leading to improved and stable incomes to the farmers. Grain legums like green gram, black gram, cowpea, etc., have been grown commonly as inter crops or in cropping rotation in the tropics since ancient times. Legumes are an important and integral component of sustainable agriculture in tropics due to their biological nitrogen fixation ability (Krishna, 2011).

An agroforestry system is viable only if both the tree and intercrop components are complementary with each other. Selection of suitable tree and crop combination and development of suitable management practices like pruning, thinning and lopping are important aspects of agroforestry research (Singh, 2009). To obtain higher production under agroforestry systems, there is need to maintain optimum spacing of trees. Hence this study was carried out to determine the appropriate agroforestry spacing for $J$. curcas in order to maximize the tree growth and intercrop yield in J.curcas intercropping system. Effect of different spacings, different intercrops and their interaction on growth and development of J.curcas was studied to explore the prospects of successfully growing intercrops with $J$. curcas.

\section{Materials and Methods}

Different intercrops were grown with three and a half year old $J$. curcas plantation at different spacings. During cropping season
$380.4 \mathrm{~mm}$ of rainfall was received and it was distributed over 27 rainy days. The experimental area contains red sandy loam, non-calcareous soil which is low in available phosphorus, available nitrogen and organic carbon and medium in available potassium. Different agricultural crops crops viz., cowpea, greengram, blackgram, groundnut, gingelly and sunflower were raised as intercrop in between $J$. curcas. Split plot design was applied to the experiment where different spacing of $J$. curcas occupied the main plots and different intercrops formed the subplot. All the intercrops were also raised as sole crop for comparison under open condition.

Plant height of $J$. curcas was measured from the base to the tip of the tree using metre scale. Pruning practices was not carried out for $J$. curcas plantation. So the number of main branches emerging immediately after collar and short clear bole were counted and recorded. The crown diameter was measured with tape in two directions; from these two readings the mean crown diameter was obtained. Light intensity under the tree and between the interspace of $J$. curcas was recorded on peak pod formation stage of intercrops using a Lux meter and expressed in Lux units. Light intensity was recorded at morning 10.00 am and afternoon at $3.00 \mathrm{pm}$. Light intensity reading was recorded in open also for comparison.

\section{Results and Discussion}

Biometric observations like plant height, crown diameter and number of branches of $J$. curcas were recorded before sowing of intercrops and after the harvest of intercrops. Different levels of spacing of $J$. curcas significantly influenced the plant height of $J$. curcas. The maximum plant height was recorded at $4 \mathrm{~m} \mathrm{x} 3 \mathrm{~m}$ both before $(261.5 \mathrm{~cm})$ and after intercropping $(310 \mathrm{~cm})$. There was a 
significant effect of intercrops on the plant height of $J$. curcas. Among the intercrop treatments the highest plant height $(315 \mathrm{~cm})$ was observed with cowpea followed by blackgram $(302 \mathrm{~cm})$. The least plant height $(270 \mathrm{~cm})$ was recorded with gingelly. The interaction effects of spacing and intercrop was not significant for plant height. However $J$. curcas at $4 \mathrm{~m} \times 3 \mathrm{~m}$ spacing with cowpea recorded the highest plant height $(332 \mathrm{~cm})$ (Table 1).

The results are in agreement with those reported by Eliakimu et al., (2015) who observed a significant increase in total height of Tectona grandis with increase in planting spacing at age of 9 years. More space available at both above and below ground level under wider spacing decreased the competition for the resources like water, light and nutrient among $J$. curcas. In Poplar and wheat based agroforestry system, Chauhan and Dhiman (2007) reported significantly higher height, dbh, crown length and crown width of the Poplar trees at $8 \mathrm{~m} \times 3 \mathrm{~m}$ wider spacing compared with closer spacing. More plant height was observed in J. curcas grown with cowpea, greengram and blackgram. This might be due to the legume effect of these crops. It was reported that survival rate was 5 per cent more and the tree height was 33 per cent higher when Casuarina cunninghamiana was combined with pulse intercrop (FAO, 1981).

The crops also help to maintain levels of nitrogen and soil organic carbon in soil through addition of residues in the soil. Pal et al., (2000) also stated that leguminous intercrops like blackgram and cowpea favoured the growth of Eucalyptus. J. curcas grown with non-leguminous intercrops like gingelly and sunflower showed least height which might be due to their more competitiveness for nutrients, water and light.
Different spacing treatment affected the crown diameter significantly. The maximum crown diameter of $212.3 \mathrm{~cm}$ and $242.8 \mathrm{~cm}$ was observed at $4 \mathrm{~m} \times 3 \mathrm{~m}$ respectively before and after intercropping. Significant effect of intercrops on the crown diameter of J. curcas was observed after intercropping. Among the intercrops the highest crown diameter (239.2 $\mathrm{cm}$ ) was observed with cowpea and the least crown diameter $(200.3 \mathrm{~cm})$ was observed with sunflower. There were no significant interaction effects between spacing and intercrop for crown diameter (Table 2). Bhuvnesh et al., (2015) also observed maximum crown width in Eucalyptus Camaldulensis at wider spacing of $3 \times 3 \mathrm{~m}$. More space between plants might have helped the lateral expansion of crown as compared to densely packed trees in narrow spacing. Wider spacing provided enough space for above ground and below ground expansion. Smaller diameters, narrow and smaller crowns were observed with closely spaced trees (Berry, 1970; Stiell, 1966). Britt and Reynolds (2011) also reported in Loblolly pine that the lower crown spread in closer spacing might be due to less availability of light as a result of more competition from neighboring trees. Intercrops may also influence the crown diameter of the main crop. Sheikh (1983) noted large crown, bigger bole and larger root system in Poplar grown in combination with legume intercrops. Better growth of Eucalyptus was observed when grown with blackgram than grown alone (Pal et al., 2000). Similar findings were reported by Gill (2005) in Acacia nilotica when planted with pulse intercrops than when grown alone. Vijaykumar et al., (1973) revealed that yield of the base crop was drastically reduced when sunflower was raised as an intercrop due to the competitive nature of sunflower for light.

A significant difference was observed for number of branches also. Maximum number 
of branches before intercropping was 13.30 and after intercropping was14.66 at $4 \mathrm{~m} \times 3$ m. Different intercrops also significantly influenced number of branches of $J$. curcas. Among the intercrop treatments the highest number of branches (12.8) was observed with cowpea. The interaction effects of spacing and intercrop was not significant for number of branches. The lowest number of branches in $J$. curcas was observed at $3 \mathrm{~m} \times 3 \mathrm{~m}$ spacing with gingelly (7.8) and highest with cowpea (15.7) at $4 \mathrm{~m} \times 3 \mathrm{~m}$ spacing (Table 3 ).

Availability of more space between trees enabled the branches to grow laterally rather than vertically to harness the sunlight efficiently. Khimani et al., (2004) reported that at wider spacing, J. curcas might grow taller with more branches. Similar findings were reported in African winter horn (Faidherbia albida) tree by Korwar and Pratibha (1999). Various intercrops also favoured significant changes in the number of branches of $J$. curcas. Among different intercrops grown, legumes viz., blackgram, cowpea, greengram and groundnut favoured more number of branches. The reason might be less competition of these intercrops for resources like moisture, light and nutrients apart from nitrogen fixation. Redhead et al., (1983) also observed more leafy branches in Leucaena when intercropped with field bean than with maize.

Light intensity under the tree and between trees was recorded at morning 10.00 am and afternoon at $3.00 \mathrm{pm}$. Different spacing of $J$. curcas significantly influenced the light availability for intercrops both under the tree and between trees during morning. The light availability in open was found to be $950 \times 100$ Lux. The highest available light under the tree was found in $4 \mathrm{~m} \times 3 \mathrm{~m}(92.9 \times 100 \mathrm{Lux})$ spacing followed by $4 \mathrm{~m} \times 2 \mathrm{~m}(85.6 \times 100$ Lux). Between trees also highest light was available at $4 \mathrm{~m}$ x $3 \mathrm{~m}(732$ x 100 Lux $)$ spacing. The lowest available light was recorded at $3 \mathrm{~m} \times 3 \mathrm{~m}$ spacing (Fig. 1). During afternoon the light availability in open was 1224 x 100 Lux. There was a significant difference in availability of light in different spacing of $J$. curcas during afternoon. Highest available light of $172.1 \times 100$ Lux and 883 x 100 Lux was found in $4 \mathrm{~m} \mathrm{x} 3 \mathrm{~m}$ respectively under the trees and between trees (Fig. 2).

Shading of the crop by the tree may be favourable, neutral or adverse to the growth of the crop (Chundawat and Gautam, 1993). In $J$. curcas based agroforestry system available light in between the trees and under the tree were low compared to open due to interception of light by the tree canopy. Among spacing, wider spacing (both under the tree and between the trees) allowed more light to the intercrops than narrow spacing probably due to less crowding of leaves in wider spaced $J$. curcas. Maghembe and Redhead (1982) reported that in agroforestry systems, compared to nutrients or moisture competition for light has a more profound influence. It is noticeable from the readings of Lux meter taken at different spacing. Higher light intensity ( $883 \times 100$ Lux) available at 4 $\mathrm{m} \times 3 \mathrm{~m}$ favoured the growth performance of intercrops.

With a little reduced light availability than in open condition, leguminous intercrops viz., groundnut, cowpea, blackgram and greengram performed better. However the yields of these crops were lower under the tree canopy compared to open condition probably due to reduced light interception. Among different spacing, intercrops under wider spacing $(4 \mathrm{~m} \times 3 \mathrm{~m})$ produced more yield because intercrops intercepted more sunlight under wider spacing which resulted in increased photosynthesis and accumulation of dry matter. 
Table.1 Effect of different spacing and intercrops on the height of J. curcas after intercropping $(\mathrm{cm})$

\begin{tabular}{|l|c|c|c|c|}
\hline \multirow{2}{*}{ Intercrops } & \multicolumn{4}{|c|}{ Spacing (m) } \\
\cline { 2 - 5 } & $3 \times 3$ & $4 \times 2$ & $4 \times 3$ & Mean \\
\hline Blackgram & 305 & 305 & 316 & 302 \\
\hline Greengram & 285 & 292 & 321 & 295 \\
\hline Cowpea & 303 & 310 & 332 & 315 \\
\hline Groundnut & 261 & 286 & 305 & 284 \\
\hline Gingelly & 247 & 271 & 292 & 270 \\
\hline Sunflower & 253 & 278 & 294 & 275 \\
\hline \multicolumn{1}{|c|}{ Mean } & 275.6 & 290.3 & 310 & \\
\hline
\end{tabular}

\begin{tabular}{|c|c|c|}
\hline Source & SEd & CD \\
\hline Spacing (S) & 3.11 & 8.5 \\
\hline Intercrop (I) & 3.64 & 7.1 \\
\hline I at S & 5.62 & NS \\
\hline S at I & 5.15 & NS \\
\hline
\end{tabular}

Table.2 Effect of different spacing and intercrops on the crown diameter $(\mathrm{cm})$ of $J$. curcas after intercropping

\begin{tabular}{|l|c|c|c|c|}
\hline \multirow{2}{*}{ Intercrops } & \multicolumn{4}{|c|}{ Spacing (m) } \\
\cline { 2 - 5 } & $3 \times 3$ & $4 \times 2$ & $4 \times 3$ & Mean \\
\hline Blackgram & 183 & 219 & 243 & 215.0 \\
\hline Greengram & 175 & 208 & 247 & 210.2 \\
\hline Cowpea & 207 & 242 & 268 & 239.2 \\
\hline Groundnut & 169 & 209 & 240 & 206.1 \\
\hline Gingelly & 174 & 210 & 231 & 205.2 \\
\hline Sunflower & 173 & 199 & 228 & 200.3 \\
\hline \multicolumn{1}{|c|}{ Mean } & 180.1 & 214.0 & 242.8 & \\
\hline
\end{tabular}

\begin{tabular}{|c|c|c|}
\hline Source & SEd & CD \\
\hline Spacing (S) & 7.51 & 20.5 \\
\hline Intercrop (I) & 4.21 & 8.2 \\
\hline I at S & 7.62 & NS \\
\hline S at I & 8.15 & NS \\
\hline
\end{tabular}


Table.3 Effect of different spacing and intercrops on the number of branches of J. curcas after intercropping

\begin{tabular}{|l|c|c|c|c|}
\hline \multirow{2}{*}{ Intercrops } & \multicolumn{4}{|c|}{ Spacing (m) } \\
\cline { 2 - 5 } & $3 \times 3$ & $4 \times 2$ & $4 \times 3$ & Mean \\
\hline Blackgram & 8.9 & 12.3 & 15.4 & 12.2 \\
\hline Greengram & 9.0 & 11.1 & 14.7 & 11.6 \\
\hline Cowpea & 9.7 & 13.0 & 15.7 & 12.8 \\
\hline Groundnut & 8.6 & 11.2 & 14.1 & 11.3 \\
\hline Gingelly & 7.8 & 11.3 & 14.2 & 11.1 \\
\hline Sunflower & 8.4 & 11.0 & 13.9 & 11.1 \\
\hline \multicolumn{1}{|c|}{ Mean } & 8.73 & 11.65 & 14.66 & \\
\hline
\end{tabular}

\begin{tabular}{|c|c|c|}
\hline Source & SEd & CD \\
\hline Spacing (S) & 0.42 & 1.15 \\
\hline Intercrop (I) & 0.10 & 0.20 \\
\hline I at S & 0.32 & NS \\
\hline S at I & 0.08 & NS \\
\hline
\end{tabular}

Fig.1 Effect of $J$. curcas on the availability of sunlight (x 100 Lux) for intercrops (during morning)

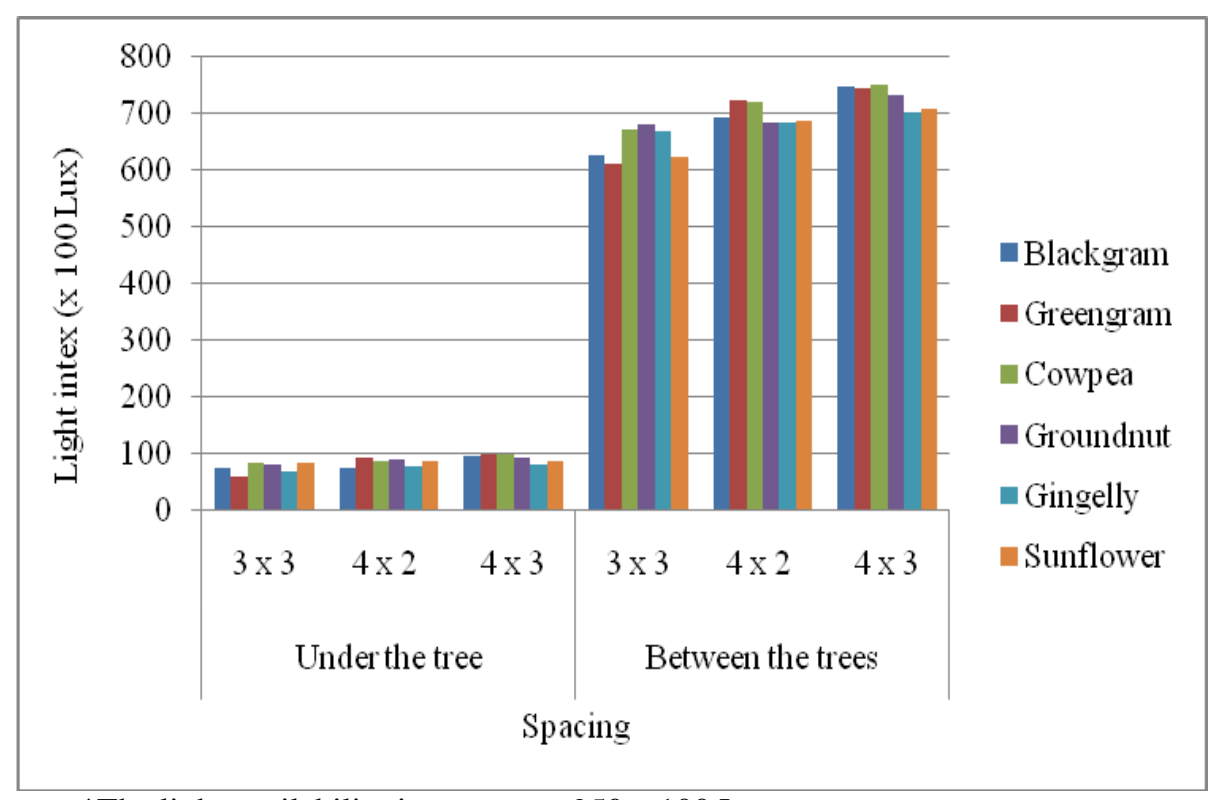

*The light availability in open was 950 x 100 Lux 
Fig.2 Effect of J. curcas on the availability of sunlight (x 100 Lux) for intercrops (during after noon)

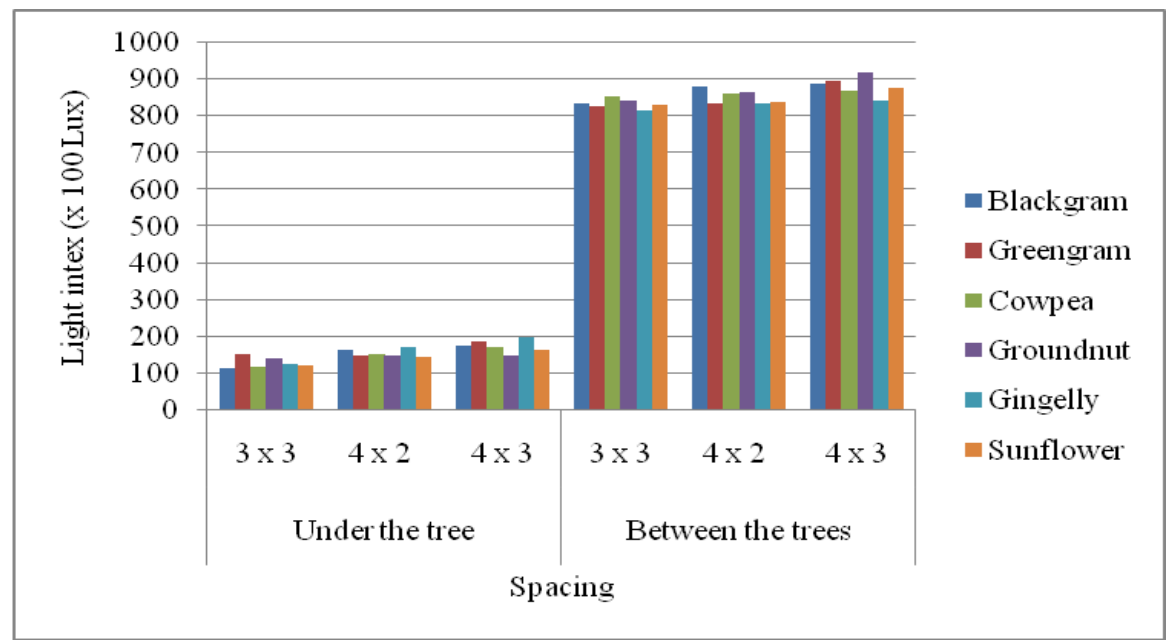

* The light availability in open was found to be 1224 x 100 Lux

Due to poor light interception, the reduction in height of cotton, sesame and sorghum was reported under Casuarina (Vinaya Rai et al., 1990). In another study progressive decrease in height, number of branches and pods, seeds per plant and per hectare grain yield in pigeon pea was observed with gradual increase in the shade of rubber trees (Brahmam et al., 1997)

The study suggests that $4 \mathrm{~m} \times 3 \mathrm{~m}$ is the optimum spacing for Jatropha curcas for intercropping. It boosts higher growth of J.curcas and can enhance productivity of associated agricultural crops by providing optimum light, less competition for moisture and nutrients, and improving soil nutrients. By integrating $J$. curcas at wider spacing farmers can obtain higher fruit production due to higher growth of $J$. curcas and improve agricultural production.

\section{References}

Berry, A.B., 1970. Spacing of Red Pine affects upper stem and crown growth. Bi-m. Res. Notes. 26 (5): 50-51.

Bhuvnesh Nagar, Sushma Rawat, Rathiesh P. and Sekar I.2015. Impact of Initial Spacing on Growth and Yield of Eucalyptus Camaldulensis in Arid
Region of India. World Appl. Sci. J.33 (8): $\quad$ 1362-1368. DOI: 10.5829/idosi.wasj.2015.33.08.247

Brahmam, M., Pillai S.S.K. and Patil,U.K. 1997. Influence of rubber (Hevea brasiliensis) tree shade on growth performance and seed yield of pigeon pea (Cajanus cajan) intercrop. Indian J. For. Res. 20(2): 181-182

Britt, J.R., and Reynolds, J.P. 2011. Volume and crown characteristics of juvenile loblolly pine grown atvarious ratios of between and within row spacing. DOI: http://www.afoa.org/ PDF/CI 1010e.pdf.

Chauhan, V.K., and Dhiman, R.C. 2007. Atmospheric humidity and air temperature studies in wheat-poplar based agroforestry system. Ind. For. 133(1): 73-78.

Chundawat, B.S., and Gautam, S.K. 1993. Tree/Crop Interface. In: A Textbook of Agroforestry. Oxford and IBH Publishing Co. Pvt. Ltd, New Delhi. pp. 124-132.

Eliakimu Zahabu, Tumaini Raphael, Shabani Athumani Omari Chamshama, Said Iddi, and Rogers Ernest Malimbwi. 2015. Effect of Spacing Regimes on Growth, Yield, and Wood Properties of Tectona grandis at Longuza Forest 
Plantation, Tanzania. Int. J. For. Res. Article ID 469760: 1-6. DOI: http://dx.doi.org/10.1155/2015/469760

FAO. 1981. Forest resources of tropical Asia. FAO, Rome.

Gill, A.S., 2005. Performance of trees in agro forestry under semi arid sub tropics. MFP News, 15(2):11-12.

Henning, R., 2003. The Jatropha Booklet. A guide to Jatropha system and its dissemination in Zambia. GTZ-ASSPProject Zambia, Mazabuka.

Khimani, R.A., Satodiya, B.N. and Jadav, R.G. 2004. Cultivation aspects of Jatropha: An over view. In: Proceedings of the National Workshop on "Jatropha and other perennial oilseed species" held 5$8^{\text {th }}$ August 2003 in BAIF Development Research Foundation, Pune, India (Eds. N.G. Hegde, J.N. Daniel and S. Dhar). pp. 77-78.

Korwar, G.R., and Pratibha, G. 1999. Performance of short duration pulses with African winter thorn (Faidherbia albida) in semi-arid regions. Indian $J$ Agr Sci.69(8): 560-562.

Maghembe, J.A., and Redhead, J.F. 1982. Agroforestry preliminary results of intercropping Acacia, Eucalyptus and Leucaena with maize and beans. In: Proc. Second Symp. Intercropping (ed. B.J. Ndunguru and C.L. Keswani). IDRC, Ottawa, Canada. p. 43-49

MPNG. 2018.Ministry of Petroleum \& Natural Gas- World Biofuel day to be observed on 10th August 2018, Posted On: 09 AUG 2018 9:36AM by PIB Delhi.

Murali Krishna, K., Neeraja Prabhakar, B. and Subrahmanyam, M.V.R. 2011.
Production potential of vegetable cowpea intercropped in Jatropha based cropping system under dryland conditions. Prog. Agric. 11(2):348351(2011)

Pal, S., Hansda, S.K. and Maiti, S. 2000. Growth of trees and grain production of crops under agroforestry system in the lateritic tracts of West Bengal. $J$ Interacademicia. 4(1): 17-22.

Redhead, J.F., Maghembe, J.A. and Ndunguru, B.J. 1983. The intercropping of grain legumes in agroforestry systems. In: Plant research and agroforestry (ed. P.A. Huxley). ICRAF, Nairobi, Kenya. p. 117-124.

Sheikh, M.I., 1983. Use of poplar and willow biomass for food, fodder and energy in Asia. Pakistan, FAO, Forest. 6: 132.

Singh. G., 2009. Comparative productivity of Prosopis cineraria and Tecomella undulate based agroforestry systems in degraded lands of Indian Desert. J. For. Res.(2009) 20(2): 144-150. DOI 10.1007/s11676-009-0025-z.

Stiell, W.M., 1966. Red Pine crown development in relation to spacing. Publ. Dep. For. Can. No. 1145. pp. 44.

Vijaykumar, R., Achuta Rao, A., Kandilkar, S.S., Tarhalkar, P.P., Harinarayana, G. and Rao, N.G.P. 1973. Sunflower research at I.A.R.I. Regional Research Station. Oilseeds J. 3: 23-25.

Vinaya Rai, R.S., Swaminathan, C. and Surendran. C. 1990. Studies on intercropping with coppice shoots of Eucalyptus tereticornis sm. J Trop For Sci.3: $97-100$.

\section{How to cite this article:}

Subbulakshmi, V., K. Srinivasan, M.P. Divya and Mani, S. 2019. Effect of Spacing and Intercropping on the Growth of Jatropha curcas and Availability of Light under Agroforestry System in Tamil Nadu, India. Int.J.Curr.Microbiol.App.Sci. 8(06): 995-1002. doi: https://doi.org/10.20546/ijcmas.2019.806.121 